\title{
Print Mass Media Strategies in Central Java and Yogyakarta Provinces to Survive the Disruption Era
}

\author{
Danar Kristiana Dewi ${ }^{1}$, Ace Sriati Rachman ${ }^{2}$, Sri Sediyaningsih ${ }^{3}$, M. Priono ${ }^{4}$, \\ Rachmawati Windyaningrum ${ }^{5}$ \\ 1,2,3,4,5 Communication Science Study Program, Universitas Terbuka \\ e-mail: danar.dewi@ecampus.ut.ac.id
}

\begin{abstract}
Article Info
Article history:

Received

July $21^{\text {th }}, 2021$

Revised

November $30^{\text {th }}, 2021$

Accepted

December $4^{\text {th }}, 2021$

Published

December $5^{\text {th }}, 2021$

Abstract

The emergence of the internet, which has the power of convergence and multiplatform, terminates the information boundaries. The information flow streaming through the internet creates numerous changes in various lifelines. One of the changes that are experienced is the information shift from print to online. This condition significantly affects print media companies, where customers and advertisers in newspapers begin migrating to a new platform, the internet. It becomes a big challenge for print media in addition to production costs that increase every year. In this era, if the print media do not immediately take action to adapt and innovate, it will be difficult to survive. Observing this development, it is essential to research to determine the strategies implemented by print media companies that currently exist to survive the disruption era. This study implemented a qualitative research method. This study's results indicate that the print media's survival strategies are innovation, collaboration, maintaining good relationships with customers, and strengthening the journalistic content production to be more attractive.
\end{abstract}

Keywords: mass media; disruption; customer relationship management

\section{Abstrak}

Kemunculan internet yang memliki kekuatan konvergensi dan multiplatfrom memusnahkan batasan informasi. Arus informasi mengalir melalui internet menciptakan banyak perubahan dalam berbagai lini kehidupan. Salah satu perubahan yang dirasakan adalah berpindahnya informasi dari tercetak menjadi online. Kondisi ini sangat berpengaruh terhadap perusahaan media cetak, dimana para pelanggan dan pemasang iklan di koran mulai bermigrasi pada platform baru yakni internet. Ini menjadi tantangan besar bagi media cetak selain biaya produksi yang meningkat setiap tahunnya. Dalam era ini, apabila media cetak tidak segera mengambil tindakan beradaptasi dan berinovasi akan sulit untuk tetap berjalan. Melihat perkembangan ini, penting dilakukan penelitian untuk mengetahui strategi yang dilakukan perusahaan media cetak yang saat ini eksis untuk bisa bertahan menghadapi era disrupsi. Penelitian ini menggunakan metode penelitian kualitatif. Hasil penelitian ini menunjukkan strategi bertahan yang dilakukan oleh media cetak untuk tetap bisa bertahan adalah dengan upaya inovasi, kolaborasi, menjaga hubungan baik dengan pelanggan, dan penguatan produksi konten jurnalistik menjadi lebih menarik.

Kata Kunci: media massa; disrupsi; customer relationship management 
Danar Kristiana Dewi et al, Print Mass Media Strategies in Central Java and Yogyakarta Provinces...

\section{INTRODUCTION}

Technology has a significant impact on human life. The internet is a new era for humans in forming an integrated, seamless, and informative ecology of life. McLuhan (2003) explained the internet constructs the distance in the world narrower but has great power. The internet encourages the communication technology revolution growth that promotes the emergence of being able to push the world into the era of the information society. Yuliar et al. (2001) explained that the information society is a condition where information flows without borders (borderless information). Information is the essence of people's lives in the information age. The information society formation as a consequence of technological developments has various impacts on human life. It is undeniable that developing technology, especially the internet, has a social and cultural impact on multiple fronts. From the disseminating information point of view, the internet character as an unlimited space for providing information breaks the monopoly flow of information that the previous generation of society has obtained.

Information is no longer controlled and regulated by conventional media. There are currently opportunities for the public to obtain information from various sources available on internet sites and social media platforms. The dominance outbreak of this information source has implications for the conventional media industry, one of which is the print media. The internet, which can be accessed easily, cheaply, and quickly, has led nearly $50 \%$ of print media readers to move or migrate to online media. The massive development of the digital world that attacked the previous technology was known as disruption (Adoni, H., \& Nossek, H, 2001).

Nimrod et al. (2015), explain disruption is an era of innovation and massive change that will fundamentally change the system, order, and perspective in new ways. As a result, players who still implement the old strategies will lose to compete. In the Comprehensive Indonesian to Indonesian Dictionary, disruption is defined as something that is uprooted.

In 2009, surprising news came from the media company in America established 137 years. It is that the Boston Globe went bankrupt. Developed countries with proper online facilities and networks, such as America and Europe, have experienced a downward trend in print media circulation. Even print media in these regions have to give up and go out of business. "Surveys have shown a decline in readership of print newspapers. In Europe and America, numerous print newspapers have stopped. The publication has completely shifted to an online edition only due to a decrease in advertising revenue" (Franklin, 2008). In Indonesia, based on a survey conducted by Nielsen, the print media readership continued to decline. From $25 \%$ in 2005 to only $19 \%$ in 2009 . While in $2015-2017$, Indonesia recognized the term "autumn" for print media. Of the 117 existing newspapers, 16 of them went out of business in 2015. Then, it was followed by other print media in a row in the next two years.

During a declining trend of readers, the print media industry has to incur substantial printing costs every day. The cost of printing per copy of a newspaper ranges from 3,000 to 5,000 rupiah. However, the selling price only ranges from 2,000 to 4,500 rupiah. It is even lower than the cost of printed production. Hence, it will be difficult for newspapers to rely on profits from print circulation. One of the most significant sources of income in print media is advertising, while the value of advertising depends on the number of circulation and readers of the print media. Thus, if you want to maintain advertisers' trust, the print media needs to perform customer relationship management properly. One of the functions of customer management is to maintain customer loyalty.

In Central Java and the Special Region of Yogyakarta, nine print media still survive nowadays. This local media must struggle to attract customers to stay in the online media era. The print media industry is not an easy industry to survive and compete in. This industry requires very high capital compared to the printing industry, which is engaged in other fields.

Theoretically, through the description above, nine local print media in Central Java and DIY certainly did the right customer management strategy to survive during the competition between print media with national scale and online media. Customer management strategy is: "Customer relationship management (CRM) as a strategy and as a technology has gone through an amazing evolutionary journey. After the initial technological approaches, this process has matured considerably - both from a conceptual and from an applications point of view. Of course this evolution continues, especially in the light of the digital transformation," (Kumar, V., \& Reinartz, W, 2018). This article discussed in-depth the customer management strategies completed by local print media in Central Java and DIY to survive. It is significant to recognize the "fate" of print media in the era of 
disruption because newspapers are one of the pillars of the nation's democracy. Specifically, newspapers play an influential role in enlightening the public on the information. The print media own this position and role, while online media cannot have a similar role because of the class gap and the content offered to each individual.

\section{METHOD}

This research used qualitative research methods, which were presented descriptively. The qualitative research model was selected because the problems studied were holistic, complex, dynamic, and meaningful. Therefore, data on this social situation could not be presented in quantitative research methods (Jensen and Bruhn, 2002). This research was in line with the qualitative descriptive format, which aims to describe, summarize various conditions, situations, or phenomena of social reality in the society as the research object, and present that reality as a feature, character, trait, model, sign, description of the condition, situations, or certain phenomena (Bungin, 2006).

The data sources of this study were obtained in two categories are primary and secondary data sources (Moleong, 2007). Primary data sources were obtained from interviews and Focus Group Discussions. Meanwhile, the secondary data sources were attained from the literature in the form of data, previous research results, books, media archive journals at the press monument, and data from the press council,

Data collection techniques in this study were adapted to the needs and studies analyzed by researchers, including:

1. Interview;

2. Focus Group Discussion;

3. Literature review by studying and analyzing books, journals, scientific articles that were relevant to the research context.

Data Recording Procedure, including:

1. The researcher recorded and transcribed the interview;

2. The researcher recorded and transcribed Focus Group Discussion (FGD);

3. The researcher documented and stored the literature review based on the use in the study and noted the citations used as reference sources in the bibliography.

The research data source sample was selected by using purposive and snowball sampling.
Determination of the sample data source in the study was temporary in the initial stage and might develop later after the researcher was in the field. At the initial stage, the sample was selected from people who have power and authority on the object under study to gain new insights for the researcher to continue collecting data.

In this study, the first sample selected was the general manager and editor-in-chief of each print media company. From collecting data through these samples, it is expected to guide the researcher in collecting data. However, in essence, by searching at the organizational structure of print media in general, the researcher also tracked the data through marketing, journalists, and print media distribution networks. It was used as a sign and limitation for researchers so that the data obtained was as needed. The analysis of the data used in this study was data analysis methods from Miles and Huberman. Data analysis was completed interactively through the process of data reduction, data display, and verification. Subjectivity in qualitative communication research was challenging to avoid. Therefore, a data validity method was needed to be used as a basis for research validity. In this study, the validity of the data was done by testing the credibility of the data. The credibility of the data was tested utilizing: re-observation, triangulation, and Focus Group Discussion (FGD) conducted with experts in mass media. Given the existing dynamics, in this study, FGD were completed so that the data were not biased.

\section{RESULTS AND DISCUSSION}

The difficult print media business conditions in 2020 were compounded by the pandemic conditions that changed the world order situations. In addition, the rising cost of paper due to the rising dollar exchange rate and the decline in advertising spending by the private sector had made the current state of the print media seem to be suffocating. The print media implemented various strategies to survive, including:

1. Collaborating or blending between print and online media;

2. Adapting to various new technological developments, both in content and marketing strategies through social media;

3. Reducing production costs by eliminating page count;

4. Becoming a multipurpose print media company, an EO, an influencer, and holding events;

5. Establishing and strengthening Print Media branding as verified information; 
Danar Kristiana Dewi et al, Print Mass Media Strategies in Central Java and Yogyakarta Provinces...

6. Joining multinational media;

7. Conducting effectiveness and efficiency of human resources either by reducing staff or not opening job vacancies;

8. Maintaining newspaper readers and subscribers by using Customer Relationship Management (CRM) methods.

The customer management method that became the discussion focus in this study was described in three parts: strategic, operational, and analytical CRM.

\section{Customer Relationship Management (CRM) Print media in Central Java}

Customer management in Central Java used three forms and levels of CRM: Strategic CRM, Operational CRM, and Analytical CRM. Strategic CRM is an effort to develop a business culture with a customer orientation (Customer-centric). The culture or organizational culture built aims to attract consumers and maintain their loyalty (Kotler et al, 2008). The way to do customer-centric CRM activities is to create value for customers that is superior to competitors. In this practice, all existing resources in the company will be allocated to support all steps to increase the company's value in the consumers' view. For example, the reward system is given to employees to improve their positive behavior towards consumers. The customer-centric method also collects customer personal data and information to support various company activities.

From the results of interviews and literature studies conducted, CRM activities on media in Central Java had a similar conclusion in managing customers. Customers must satisfy with the result of media products. Customer satisfaction with this media product was viewed from two sides: the editorial (news content) and the price list.

In terms of content, readers should obtain accurate, credible, and fair information. Thus, with proper content, customers can receive the information they need credibly. Print media must be a trusted information guide for society. Collecting information and the verification process done by the editor makes the print media much more comprehensive in information. It can be the power of print media and the added value of print media in customers' views.

In terms of the price list, the reader must benefit according to the nominal issued. It means that the product that reaches the reader's hands is considered representative and in line with the number of subscription fees, or even the benefits obtained can be more than the costs incurred. Thus, the released media products usually follow their market segment. For example, the media reader segment is in the age range of 40-60 years. Hence, the newspaper designs, themes, materials, and information in the media are adjusted to customer needs.

Satisfaction orientation to newspaper subscribers was also completed by optimizing the distribution of print media. In Central Java, the distribution of print media must be done on time. Newspapers or print media must have been distributed to customers maximally at 06.30 WIB. Nico, an employee of the Solopos circulation division, confirmed, "If it is more than 06.30 WIB, customers will protest and complain because they are in a hurry to go to the office or do other activities."

Integration between divisions in print media companies in Central Java was also done to produce harmony and continuity in producing good products. Thus, the customers will feel satisfied. For example, in Radar Solo and Solopos, integration between editorial and circulation departments was completed daily. The integration was circular communication between the editors, marketing division, circulation section, and agents. Issues raised in editorial meetings would be continued by the marketing division to the circulation section to print media agents. Furthermore, the print media agent would place an order for circulation according to the issues raised by the media because it is the newsagent who best knows the society's interest and virality of problems.

In several media, this strategy was used so that the printed newspapers were suitable with the quantity ordered by the newsagents. Thus, no newspaper prints were wasted because the market did not absorb them. This strategy was also implemented to meet customer needs in the region. When there was an element of customer proximity to the hot issue that would be raised, it was certain that demand would increase. If this circular pattern was not made within the company, the customers' expectations of print media could decrease. Circular communication patterns between companies, newsagents, and customers can be seen in Figure 1.

In this strategic CRM strategy, print media also made efforts to create a customer-oriented organizational culture within the company. Creating a customer-oriented organizational culture was done by creating value for customers through internalization of employee work culture and taglines in print media. Thus, it can create a particular image in society. In Harian Solopos, we can see the tagline in its print 


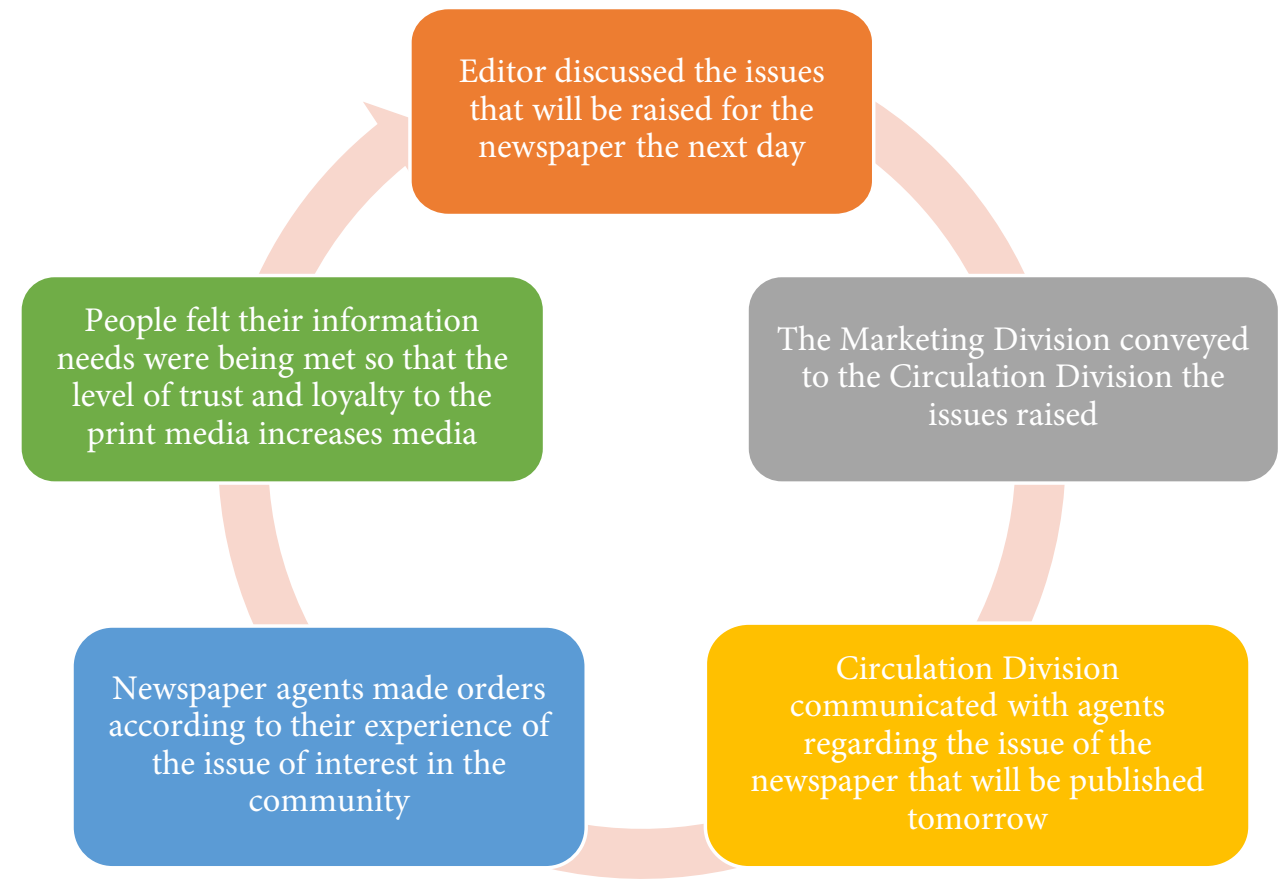

Figure 1. Circular Pattern in print media

media as a Trusted Information Guide. From this tagline, Harian Solopos wanted to create an image as a credible media with the products produced can be accounted for to customers.

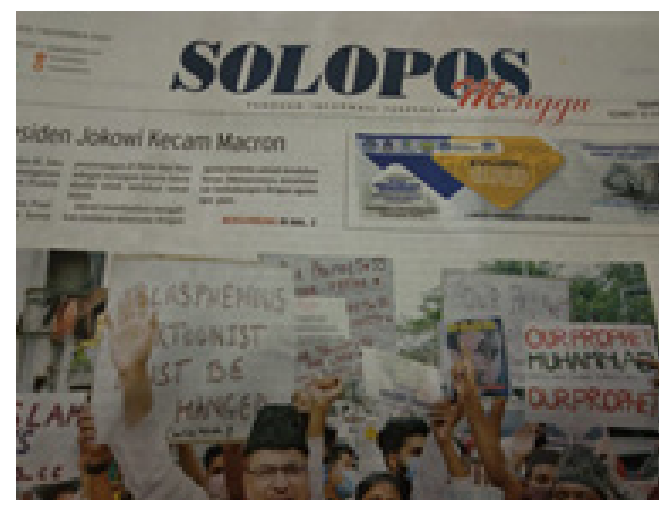

Figure 2. Local Print Media

Previously, the tagline in this Harian Solopos was to guard the dynamics of the community. This tagline changed because Solopos wanted to answer the challenges in the digital era, where at this time, the migration of readers to digital platforms was inevitable. Responding to this condition, the strength of print media was in verified and trusted content or news. News in print media tended to be safer than hoax news scattered in online media. Through this tagline, Solopos wanted to emphasize the position of print media in the proliferation of existing online media.
Print media provided rewards to maintain customer satisfaction in various forms. This reward was usually given in the form of a bonus in the form of a special price if you subscribe, or it can be served in the form of an editorial. Print media in Central Java also used Operational CRM in their customer management strategy. Operational CRM focused on automating the way companies reach and connect with consumers. In the operating CRM system, technology and application support were strongly useful for improving sales and service functions to run automatically through the system. Three vital application components must be in Operational CRM, including marketing automation, sales, and service.

In marketing automation, three sub-applications were usually used in conducting operational CRM: market segmentation, communication campaign management, and event-based marketing. Marketing automation is the process of utilizing technology in marketing processes. Marketing automation software offers several capabilities at once, including market segmentation, communication campaign management, and event-based marketing. This software makes it easier for users to use and explore customer data to establish communication and provide offers to potential customers.

The use of software done by the mass media in marketing automation was realized by media integration and collaboration. The current technological developments generated the media 
Danar Kristiana Dewi et al, Print Mass Media Strategies in Central Java and Yogyakarta Provinces...
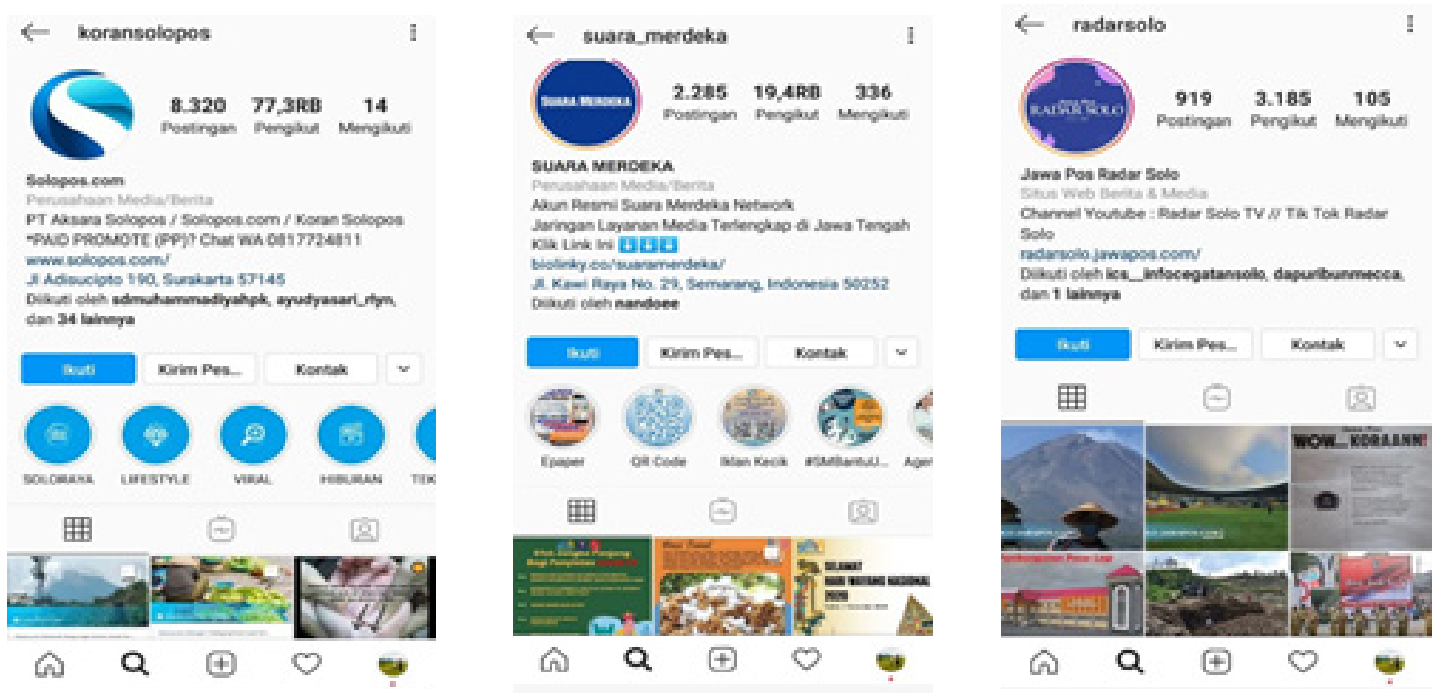

Figure 3. Social Media Solopos, Suara Merdeka, Radar Solo

(Source : www.instagram.com)

have digital platforms that are developed based on the internet. This digital platform can produce research for print media to reveal their market segmentation based on reached and engagement data that occurred on the digital platform. This digital platform can be in the form of social media, both Facebook and Instagram. In their social media, print media performed: interacting, communicating, and also organizing virtual events. From the process conducted, the data obtained can be processed as prospective customer data.

The second is sales force automation; this system is based on the Sales Forces System (SFA) software. This system applied technology in managing various company sales activities. The sales processes can be broken down into several stages: prospecting, qualifying prospects, identifying the need, developing the specification, creating the proposal, overcoming rejection, and realizing sales.

The Sales Force System (SFA) activity in this CRM activity cannot be separated from the use of technology used by the company, where the combination of technology and people in customer management was a hallmark of the CRM strategy. Sales Force System can be seen in several aspects. The first is Sales Cloud. It aims to optimize the sales, revenue, productivity, and visibility of a business. The second is Service Cloud. Finally, it is helpful as an effort to establish good relationships with customers.

Sales Cloud and service cloud were conducted simultaneously by print media. The implementation of this SFA was usually done in the marketing or marketing department, whose job is to obtain advertisements in print media. As explained in the previous chapter, in print media, the definition of customer is defined as an advertiser and a reader. In SFA activities: cloud sales and cloud services were completed by providing offers and bonuses to advertisers. Then, cloud services were done to customers by establishing good communication with advertisers, identifying advertisers' needs, providing editorial services to advertisers, and creating virtual events through social media print media to provide services to advertisers.

Third is Marketing Cloud: Work through social media for marketing enhancement. The four are Salesforce Platforms and AppExchanges: Focus on mobile and Real-Time social media on the right platforms. Fifth, Salesforce Chatter: Help the business process itself, especially through social media. Print media conducted cloud marketing and sales chatter in integrating with their online media. In Solopos, as a media that has several platforms, online media has different social media. For example, print media had an Instagram account for Solopos newspapers, and online media solopos.com had a solopos.com Instagram as its social media account. Each function as a marketing cloud and a sales force chatter, even though we can also find collaboration and integration between the two. The last CRM strategy is service automation. With this system, the company can automatically conduct customer functions by performing call centers and contact centers. Print media had a contact service that can be contacted separately. The first was customer complaint service related to print media products' editorial and content. The second was service or customer contact related to product circulation and distribution. Customer data owned by the circulation and customer complaints department was used as a 
database to reveal the typical customers owned by the company so that it can be used for product upgrades.

\section{Customer Relationship Management (CRM) Print media in Yogyakarta}

Yogyakarta Province has a long history in the print media. Like in Solo, Jogja has the term "newspaper graveyard" because many companies had lost in the media industry, especially print media. There was a mass media in Jogja that has been established since Indonesia's independence. This media is Kedaulatan Rakyat (KR). Before the emergence of many printed mass media in Yogyakarta, KR was a media that strongly influenced Yogyakarta. KR even has strong brand awareness in the people of Jogja until they referred to the term Koran as KR.

Over time, various print media appeared in Yogyakarta, such as the Harian Jogja, Radar Jogja, and Tribun Jogja. The presence of these media triggered newspaper competition in Yogyakarta very tight. It took a lot of effort to break the strong KR brand to attract customers. Currently, one of the fastestgrowing newspapers in Yogyakarta is Tribun Jogja. Tribun Jogja, even though it was only established in 2011, can appear successfully and obtain customers.

The primary strategy done by Tribun Jogja was to differentiate the segmentation between Tribun Jogja and KR. The market segmentation targeted by Tribun Jogja was precisely the millennial generation and productive age ranging from 15 to 35 years. In contrast, the KR market segmentation was a mature generation aged 40-60 years. It can also be seen from the print media's appearance between Tribun and KR, which had different styles. In facing the era of disruption, these two media had strategies to deal with it because the target market and customers were different. The way these two media did customer management will be discussed in three parts of customer relationship management: strategic, operational, and analytical CRM levels.

The essence of strategic CRM is that the way to conduct customer-centric CRM activities. It is to create value for customers that is superior to competitors. $\mathrm{KR}$, a newspaper that has been established early, had attracted society's interest in Jogja, especially those of mature age. Therefore, the content on KR also adjusted to the existing customer segmentation. It is done to increase customer satisfaction. It can be seen from KR's media appearance and writing style, which tended to be simple and iconic. The language chosen was also polite and did not display bombastic and phenomenal titles.

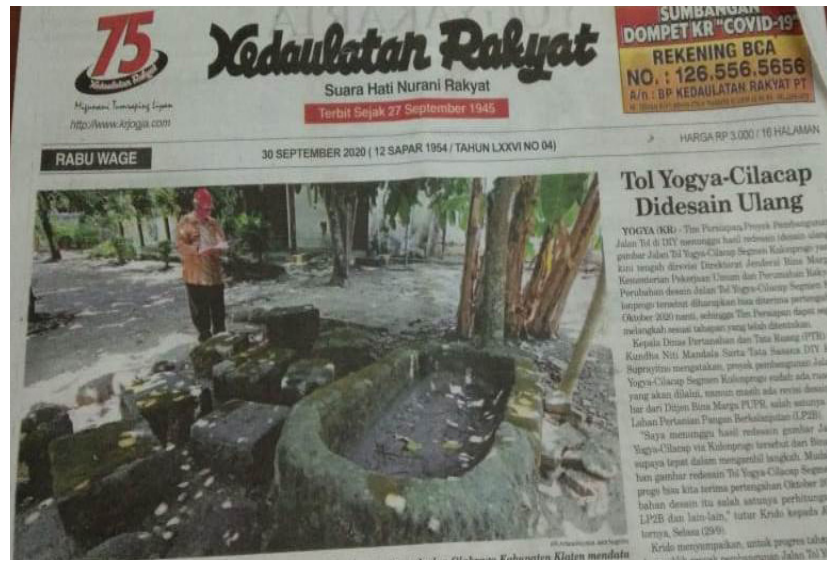

Figure 4. Local Print Media in Yogyakarta

Tribun Jogja did something different. With customer segmentation between 15-35 years old, content and visualization were the main issues displayed by print media. The appearance of the media presented by the Tribun followed the interest of market segmentation at this age. "With our market segmentation, interesting content is an absolute must; Tribun must present something they like, from themes, news, to writing" (Ikrob, Tribune's digital manager)

The writing style of the stands was adapted to the tastes of the targeted market. At that age, customers in the frames like issues that are dramatic. With the results of this research, Tribun Jogja then made a writing style suitable to the characteristics of the drama. The writing plot was made in three parts: storyline, conflict, and conclusion. From this writing style, a new writing style emerged in print media, namely: micro people. This writing style made news writing from the point of view of dramatism and humanism. With the content of this article, Tribun Jogja managed to print 40 thousand newspaper circulations every day. Then in terms of media appearance, Tribun tended to be more daring and attractive because young people dominate media customers.

The operational CRM did by the print media in Yogyakarta to manage customers consisted of several parts. First, in the marketing section, Tribun Jogja did unique marketing. Subscribing to the newspaper was done every month. However, Tribun Jogja made a unique policy, namely the annual newspaper subscription fee. So, customers who subscribed to the newspaper directly in one year would obtain benefits in discount vouchers given by the Tribun from the collaboration between advertisers.

This strategy was effective in increasing the 
number of customers and the number of advertisers. On the one hand, customers benefited from getting around 32 discount vouchers from various merchants in Yogyakarta with a nominal that was undoubtedly more than the subscription fees incurred. On the other hand, advertisers benefited from controlling the effectiveness of advertisements done in the daily stands through the number of vouchers exchanged to merchants.

At $\mathrm{KR}$, the marketing strategy was done by increasing the network and entering the communities in Yogyakarta. In addition, KR also organized national-scale events that can open up opportunities for sponsors to enter and fund the activities conducted. In terms of incoming advertisements, KR was actively managing advertisements in the form of advertorials. Advertorial advertisements were advertisements in the form of narratives so that they seem to be more soft selling.

Analytical CRM done by print media in Yogyakarta was conducted with collaboration and adaptation strategies. Currently, almost all print media, as the research object of this study, had their online media. Online media had become a form of media convergence and collaboration within the company. The provision of this online platform was made as a form or strategy to stem the flow of customer migration and maintain customer age and keep the print media brand into digital readers.

\section{CONCLUSION}

Print media, as newspapers, will probably dim and have a small market share. However, they, as information media, will still exist. Their forms were transformed into another form following technological developments that require them to converge. Print media will carry out a metamorphosis in form, distribution model, way of working. Although print media will still exist, innovation is still very necessary to meet the needs of the community. To move quickly and keep pace with the pace of digital technology, the media need to collaborate and synergize with stakeholders.

\section{ACKNOWLEDGEMENTS}

I would like to thank the Universitas Terbuka for providing opportunities for young lecturers to dare to work. In particular, I would like to thank FHISIPUT and UPBJJ-UT Surakarta, which is where I work.

\section{REFERENCES}

Adoni, H., \& Nossek, H. (2001). The new media consumers: Media convergence and the displacement effect. Communications. The European Journal of Communication Research, 26(1), 59-83.

Bungin, B. (2008). Penelitian Kuantitatif. Jakarta: Kencana. Kumar, V., \& Reinartz, W. (2018). Customer relationship management. Springer-Verlag GmbH Germany, part of Springer Nature 2006, 2012, 2018.

Franklin, B. (2008). The future of newspapers. Journalism Practice, 2(3), 306-317.

Hamdiah, Diana Fajri. (2020). Pelaksanaan Event Marketing dan Customer Relationship Management di The Jakarta Post. Internship thesis, Universitas Multimedia Nusantara.

Jensen, Klaus Bruhn. (2002). "Handbook of media and communication research, Qualitative and Quantitative Methodologies." London: Routledge.

Kotler, Philip and Amstrong, Garry. (2008). Prinsip-Prinsip Pemasaran Jilid I. Jakarta: Eralangga.

McLuhan, M. (2003). Understanding Media: The Extensions of Man (critical edition). W. Terrence Gordon (Ed.), Corte Madera, CA: Gingko Press.

McQuails, Dennis. (2011). Teori Komunikasi Massa Ed. 6 (terj). Jakarta: Salemba Empat.

Moleong, Lexy J. (2007). Methodologi Penelitian Kualitatif. Remaja Rosdakarya; Bandung.

Nimrod, Adoni, Nosek etc. 2015. Is Print Really Dying? The State of Media Use in Europe. International Journal of Communications, 9, 365-385.

Nossek, H., \& Adoni, H. (2007). The global village, the nation-state, and the ethnic community: Audiences of communication and boundaries of identity. In R. Watson \& M. Blondheim (Eds.), The Toronto School of communication theory: International perspectives (pp. 237-271). Toronto, Canada: University of Toronto Press and Jerusalem, Israel: Magnes, Hebrew University Press.

Yuliar, S. et all. (2001). Memotret Telematika Indonesia Menyongsong Masyarakat Informasi Nusantara, Bandung: Pustaka Hidayah. 